\title{
Physical and chemical characterization of a spring flood event, Bench Glacier, Alaska, U.S.A.: evidence for water storage
}

\author{
Suzanne Prestrud Anderson, ${ }^{1}$ Katherine M.H. Fernald, ${ }^{1}$ Robert S. Anderson, ${ }^{1}$ \\ NeIl F. Humphrey ${ }^{2}$ \\ 'Department of Earth Sciences and Institute of Tectonics, University of California, Sanla Cruz, California 95064, US.A. \\ ${ }^{2}$ Department of Geology and Geophysics, Lniversity of Wyoming, Laramie, Wyoming 82071, U.S.A.
}

\begin{abstract}
Previous studies of alpine glaciers have demonstrated that as water discharge increases through the summer, the predominant mode of subglacial drainage shifts from a distributed system to a more efficient conduit drainage system. We observed an earlymelt-season speed-up and flood event lasting roughly 2 days in a small, uncomplicated Alaskan glacier that appears to have resulted from a sudden shift of the subglacial system in response to a significant accumulation of mcltwater within the glacier. Calculated meltwater inputs excceded discharge before the event; the implicd change in storage over this 10 day period was equivalent to roughly $0.13 \mathrm{~m}$ averaged over the entire glacier bed. The pattern of discharge and suspended-sediment variations and the appearance of large ice chunks in the stream suggest that the speed-up occurred during a period of establishment of new subglacial conduits. A culminating flood and associated suspended-sediment pulse appear to have marked the final establishment of the new section of subglacial conduit. The flood ended the episode of high sliding velocity, but released water with high solute concentrations that reflect relatively long contact time with sediments. Discharge of stored water, inferred from high solute concentrations and lack of diurnal variation in discharge, continued for at least 3 days. While events such as this must recur through the melt season as the conduit system extends up-glacier and the locus of meltwater inputs shifts, their manifestations in the outlet stream will likcly be more subdued later in the season.
\end{abstract}

\section{INTRODUGTION}

A linkage exists between glacial hydrology and glacier sliding. 'The linkage is manifested in the concurrence of periods of high watcr pressure measured in borcholes and high sliding velocity (Iken and Truffer, 1997), in pulses of turbidity associated with "mini-surge" behavior at Varicgatcd Glacicr, Alaska, U.S.A. (Humphrey and others, 1986), in coincident increases in suspended-sediment concentration and straining on the ice of Black Rapids and Fels Glaciers, Alaska (Raymond and others, 1995), and in the correlation between large water inputs from melt or rain and rapid sliding at Storglaciären, Sweden (Hooke and others, 1989; Jansson, 1996). High basal water pressures expand the size of cavities at the bed, which reduces the area of frictional coupling at the bed and reduces effective stresses (Iken and Bindschadlcr, 1986). Subglacial water also cxerts a down-glacier force on the ice that drives sliding, an effect likely to depend on the volume of stored water (Humphrey, 1987). Work on Columbia Glacier, Alaska (Kamb and others, 1994; Meier and others, 1994), has suggested that because the water-pressurc ficld at the bed may be highly localized, a better surrogate for the role of water in modulating glacier sliding may be the water storage at the bed. At Unteraargletscher, Switzcrland, Iken and others (1983) corrclated maximum upward movement rates with maximum sliding velocities, and inferred that the uplift was accommodating water storage at the bed.
Understanding the intimate coupling between the hydrological state and sliding-rate pattern of a glacier should provide insight into the controls on subglacial abrasion and quarrying, both of which require sliding. In addition, as water chemistry in the glacial system is coupled to the pathways and residence times within various reservoirs that include the subglacial cavity system, the chemistry of the glacier outlet stream can potentially be used as a probe of the systcm (Tranter and others, 1993; Collins, 1995; Brown and others, 1996b).

Brief (non-surge) episodes of high sliding velocities can occur in any part of the melt season and in any part of the glacier. In spring, the subglacial hydrologic system is thought to undergo a progressive reorganization from one dominated by a distributed flow system to one with conduits that can efficiently transmit meltwater to the terminus (Fountain and Walder, 1998; Hubbard and Nienow, 1998). Here, we present observations of a spring speed-up and flood event at Bench Glacier, Alaska, in which several lines of evidence suggest that the formation of conduits occurs forcefully when the distributed system is overwhelmed by meltwater inputs. We collected data in June, early in the melt season, when this subglacial reorganization is likely to be occurring close to the terminus of the glacier, and hence its manifestations in the outlet stream are not diffused by long travel distances. Importantly, since the flood event we recorded followed 9 days of clear weather, it cannot be attributed to storm input. In addition to measuring ice velocity, 
snowmelt, water discharge and sediment concentrations, we made detailed observations of the chemistry of the outlet stream.

\section{FIELD SITE AND METHODS}

Bench Glacicr, in the Chugach Mountains of south-central Alaska (Fig. l), is comparable in size to the well-studicd Worthington Glacier $12 \mathrm{~km}$ to the north (Harper and others, 1996, 1998a, b; Welch and others, 1998). Its present footprint of $9.0 \mathrm{~km}^{2}$ is remarkably simple in plan. Bench Glacier has no tributarics and, with the cxception of one icefall, slopes fairly uniformly at $10^{\circ}$ until within approximatcly $1 \mathrm{~km}$ of its terminus. The present terminus is at an elevation of $945 \mathrm{~m}(3100 \mathrm{ft})$, and the headwall is surrounded by peaks up to $2151 \mathrm{~m}$ (7057 ft). The total basin area above our gauge is $12.5 \mathrm{~km}^{2}$. The single outlet stream yields maximum discharges of order $10 \mathrm{~m}^{3} \mathrm{~s}$. The glacier is therefore well suited for a variety of investigations, including those that rely upon capturing the discharges of both water and sediment using simple field instrumentation methods.

The present terminus of Bench Glacier is $2-2.5 \mathrm{~km}$ back from its Little Ice Agc (LIA) terminus position. Although the timing of the LIA maximum has not been established at Bench Glacier, it is likcly to be similar to the history on the west side of Prince William Sound, wherc trec-ring chronologies show that two glacier culminations of nearly equal size occurred in AD 1710 and AD 1870-1900 (Calkin, 1988; Barclay and Calkin, 1996). Bench Glacier has retreated $800 \mathrm{~m}$ since 1950 , when the aerial photography for the L.S. Geological Survey (USGS) topographic map (Valdez A-5, 1:63360) was done. These observations yield average modern retreat rates of $20 \mathrm{~m} \mathrm{a}^{-1}$.

The glacier is underlain by late-Cretaceous age metasediments of the Valdez Group (Winkler and others, 1981; Plafker and others, 1989). Bedrock does not crop out on the proglacial valley floor, but does appear in isolated outcrops low on the valley walls. Gullies cut into the valley walls attain depths of up to $3 \mathrm{~m}$ entirely within glacial till; this suggests that a subglacial till layer of at least this thickness occurs under the glacier itself.

We visited Bench Glacier for 16 days in June 1996. During that time, we monitored ice velocity, stream discharge, suspended-sediment concentration, water chemistry, air temperature and snowmelt rates. At the beginning of the period, no ice was visible on the glacier; on the last day, the snowline was at $1370 \mathrm{~m}(4500 \mathrm{ft})$, and roughly $30 \%$ of the glacier was snow-free.

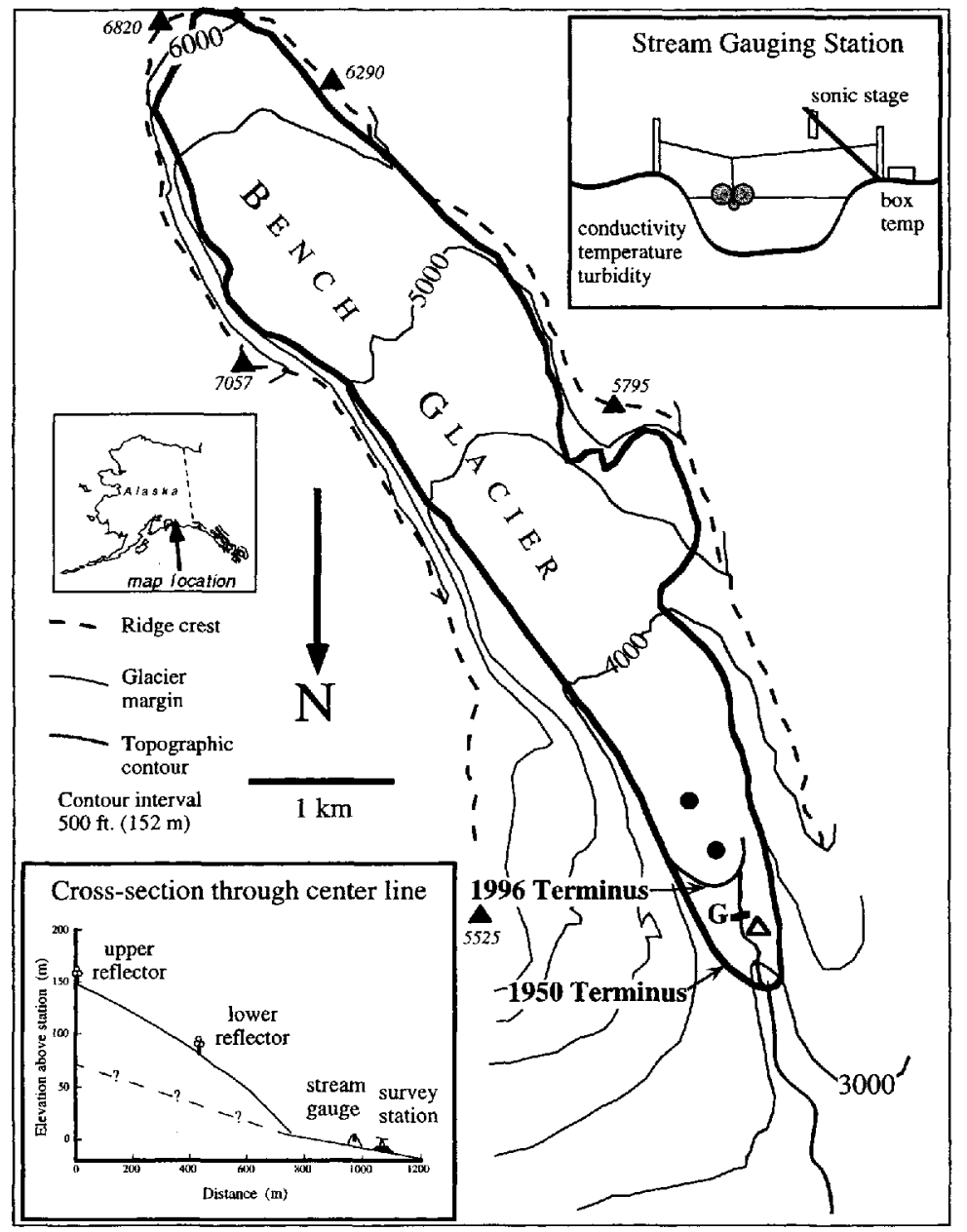

Fig. 1. Map of Bench Glacier. Contours are $500 \mathrm{ft}(152 \mathrm{~m})$, and spot elevations are in feet. Drainage divide is dashed, shoreing nearly full occupation of the valley area by ice except for recently deglaciated small cirque near the terminus on glacier-right. Detail of the lerminus area includes the gauging station $(G)$, the survey station (open triangle) and the two reflectors on the ice surface (filled dots), all of which are shown in cross-section in the bottom left inset. Comparison of the 1950 lerminus, from the USGS Valdez (A-5) $15^{\prime}$ quadrangle, and the 1996 terminus documents roughly $20 \mathrm{ma}^{-1}$ of retreat. Stream-gauge set-up is shown in upper right inset, including tethered "fish", boom supporting acoustic sensor for stream stage, and data-logger box in which box temperature zeras logged as well. 


\section{Ice velocity}

We used an isolated, $20 \mathrm{~m}$ tall moraine hill located near the center of the Bench Glacier valley, $300 \mathrm{~m}$ from the present terminus, as a base for observations of glacier motion (Fig. 1). This location afforded a line of sight up the center of the glacier, parallel to the expected ice-flow direction. A total station survey instrument (HP-3810B medium range) was set up on the moraine hill, and remained in place for the entire field visit. Two triple reflectors were installed on the ice approximately 663 and $1062 \mathrm{~m}$ from the station. Because the viewing angle was closely aligned with the flow direction, displacements of the reflectors toward the total station are interpreted directly as ice displacements. The reflectors were mounted on small sections of drill rod augered into the icc surfacc. Distances to the reflectors were measured at irregular intervals ranging from a few minutes to a few hours. The reflector poles were re-augered once, and were still firmly in their narrow holes when we departed. Given the time of our visit, we could measure distances in all but a few hours of the day, limited only by very late night darkness and occasional dense clouds.

\section{Stream gauge}

While the Bench River is braided close to the terminus, it becomes a moderately stable single thread incised into its banks by about $1 \mathrm{~m}$ where it crosses the moraine on which the total station was located. We installed a stream gauge, similar in design to that of Humphrey and others (1986), consisting of an acoustic water-stagc sensor and surfacewater conductivity, turbidity and temperature sensors. During the highest discharges, we defeated the stream's pernicious attempts to braid upstream and divert flow around the gauging station by placing numerous boulders at the sites of breaches. Our minor modifications were sufficient to cause deposition by the channel at these spots, and keep the course unchanged past our gauge. At the most, a few per cent of the total flow leaked around the gauge at the highest discharge

The temperature-compensated acoustic water-stage sensor (Lundahl) was cantilevered above the water surface with polyvinyl chloride (PVG) pipes. Each stage measurement consisted of an average of 100 readings in a $10 \mathrm{~s}$ period to reduce the noise associated with unsteady roughness of the water surface. Stage was recorded by a Campbell CR10 data logger every $15 \mathrm{~min}$.

Watcr temperaturc, clectrical conductivity and turbidity were measured with a floating instrument package (Fig. l, upper right inset). The instruments were banded to the bottom of a raft constructed of two sealed PVC pipes filled with closed-cell foam. The package was tethered to a steel cable across the river, and floated near the center of the flow for the first 10 days of the field visit. The cable failed upon collapse of the right bank, and thereafter, the package was tethered within $0.5 \mathrm{~m}$ of the left bank. The conductivity time series was much less noisy when the package was floating in the less turbulent water near the bank. The turbidity and conductivity signals did not show any other changes at tributable to moving the sensors out of the channel talweg.

The turbidity sensor, patterned after Stone and others (1993) and Humphrey and Raymond (1994), measures light intensity after passage across a $10 \mathrm{~mm}$ water-filled gap from a light-emitting diode (red) source. Ambient light is blocked by a scrics of black PVG baffles on cither side of the measurement section of the tube, and water is allowed to pass through the tube. We found the sensor worked best when the baffles were oriented vertically, reducing the likelihood of accumulation of sediment within the tube as the flow is forced from side to side. Coarse sediment is prevented from entering the tube by a screen at the upstream end of the tubc.

Water temperature was measured using a thermistor, and conductivity was measured using a commercial conductivity probe, both of which were attached to the turbidily sensor body.

\section{Discharge rating curve}

We used the salt-dilution method (Kilpatrick and Cobb, 1984; Kitc, 1994) or current-meter and channcl crosssectional area measurements to establish the discharge at 13 stages corresponding to the full range of discharges we witnessed. The salt-dilution method entailed injection of $1-2 \mathrm{~kg}$ of salt dissolved in $20 \mathrm{~L}$ of stream water, and measurement of time serics of conductivity in the strcam $100 \mathrm{~m}$ downstream. As the channel was typically $\overline{0}-8 \mathrm{~m}$ wide, this distance was more than the recommended 6-10 channel widths (Kite, 1994) necessary to ensure full mixing of the salt. The baseline conductivity, $\Psi_{0}$, was established before salt injection, and we recorded data until we were confident that the flow had retained this baseline. The time series, $\Psi(t)$, was collected at 5 s time-steps to ensure sufficient detail to obtain well-constrained integrals of the conductivity signal. We have done repeated salt discharge measurements elsewhere that suggest that crrors in the deduced discharges are only a few per cent. The conductivity, $\Psi$, was related to salt concentration through $C=b \Psi$, where the constant $b=\left(1 \mathrm{~kg} \mathrm{~m}^{3}\right)$ $\left(214 \mu \mathrm{S} \mathrm{mm}^{-1}\right)$. Discharge was then calculated from the mass-balance relationship,

$$
Q=\frac{M_{\mathrm{s}}}{b \int_{0}^{T}\left[\Psi(t)-\Psi_{0}\right] \mathrm{d} t}
$$

where $M_{\mathrm{S}}$ is the mass of salt injected, and the time interval $t=0-\mathbf{T}$ for the integral is that required for the entire salt wave to pass the observation station, i.e. for the conductivity signal $\Psi(t)$ to return to the background valuc, $\Psi_{0}$.

The rating curve (Fig. 2) is constructed using the acoustic-stage measurement nearest the time of discharge measurement. The two discharge measurements at the lowest acoustic stages fall off the linear trend defined by the other data points. These two measurements were made on 26 Junc, aftcr a flood event (Fig. 3). We believe that the difference between these two points and the rest of the data is real; they are consistent with the shift expected for aggradation of the bed. We therefore used two rating curves, switching from the pre-26. June curve at $1315 \mathrm{~h}$ on 26 June, shortly before our discharge measurements that day, at the beginning of a $90 \mathrm{~mm}$ rise of the water surfacc in $75 \mathrm{~min}$, the most rapid rise we recorded (Fig. 3). The resulting discharge curve varies smoothly across the switch in rating curves, instead of displaying the sharp jump on 26 June seen in the stage record (Fig. 3). Although the shifted rating curve is based on only two measurements, and therefore is not as well characterized as the pre-26 June curve, failure to make this adjustment results in calculated discharges that are greater than any of our measurements (i.e. constitutes an extrapolation rather than an interpolation of our data). In particular, discharges calculated using the pre-26 Junc rat- 


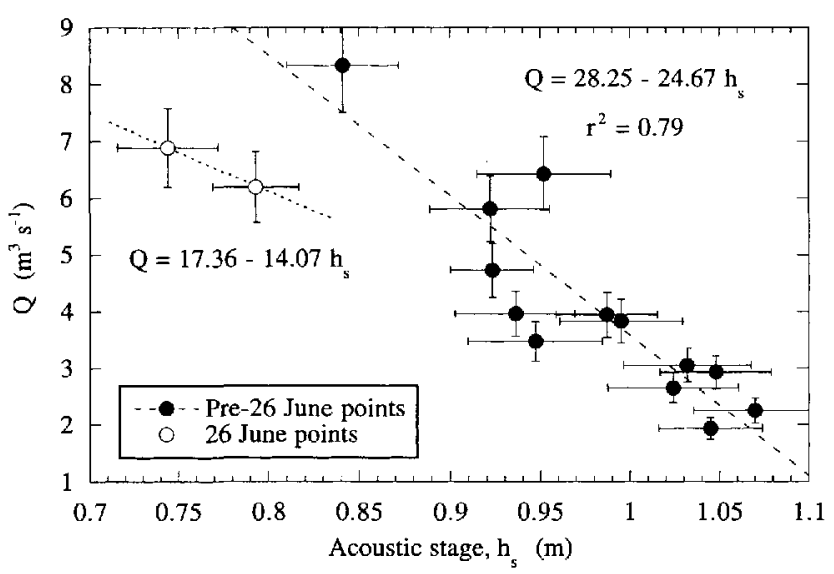

Fig. 2. Discharge ratingcurves. Acoustic stage is distance from sensor down to the water surface, and hence varies inversely with discharge. Horizontal error bars are $\pm 1 \sigma$ for the acoustic-stage measurements, which are averages of 100 readings over $10 \mathrm{~s}$. Vertical error bars are $\pm 10 \%$. Data for 26 . June (open circles) were collected after the spring flood event. Differences in the two curves reflect aggradation of the bed.

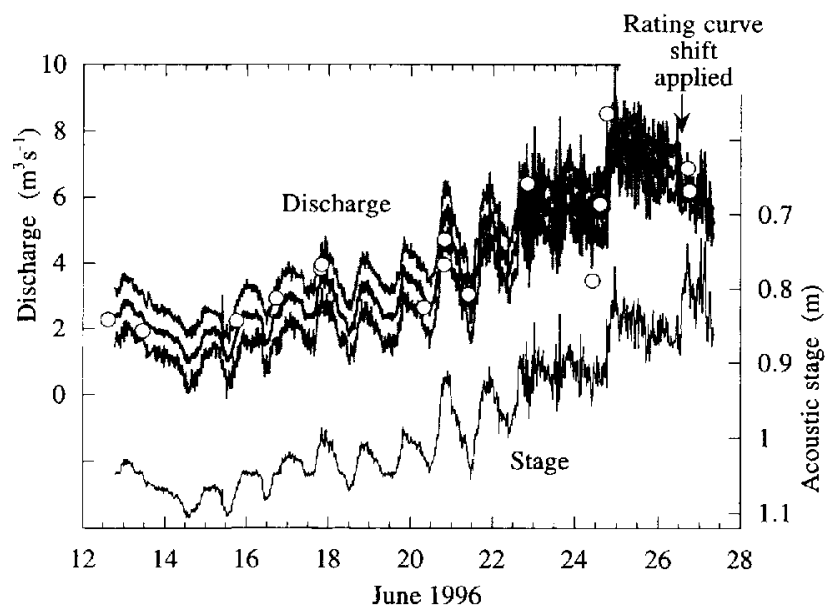

Fig. 3. Stage and discharge records. Lower curve shows acoustically measured stage, plotted with y axis rezersed, while. upper set of curves showes calculated discharge (black) and $\pm 1 \sigma$ based on noise in acoustic-stage data (gray). Discharge measurements are shown with open circles. The last two discharge measurements, on 26 June, zeere accommodaled only by switching to a new rating curve (Fig. 2). The shift in rating curves was applied at the beginning of the large step in acoustic slage at midday on 26 fune, and results in calculated discharge showing a falling trend for observations after the 24 June peak.

ing curve exceed our measurements on 26 June by nearly $3 \mathrm{~m}^{3} \mathrm{~s}^{1}$.

Errors in our rating curve and discharge mcasurements are greatest at high discharge. Acoustic stages around $0.9 \mathrm{~m}$ associated with the onset of the 24 June flood were especially noisy at the measurement site, because the flow gencrated standing waves many $\mathrm{cm}$ in amplitude. If the time for a standing wave to pass the sensor location is different than the 15 min measurement frequency, then a single measurement could misrepresent the mean flow significantly, in cither direction. The errors are as large as $1 \mathrm{~m}^{3} \mathrm{~s}^{-1}$ at the high flows (Fig. 3). In addition, the roughness of the water surface during any $10 \mathrm{~s}$ mcasurement contributes noisc of $\pm 15 \mathrm{~mm}$ to the stage measurement, the effect of which is shown by the gray lines in Figure 3. Finally, our salt-dilution and currentmeter measurements of discharge are not without error.

\section{Suspended-sediment rating curve}

Water samples were collected twice daily in $250 \mathrm{~mL}$ polyethylene bottles at the surface of the stream for solute and suspended-sediment analysis (Ostrem, 1975). When the floating instrument package with the turbidity sensor was located close to the channel bank, these samples were collected within $0.5 \mathrm{~m}$ of the sensor. For most of the study, however, water samples were collected $2-5 \mathrm{~m}$ from the turbidity sensor, usually slightly upstrcam. Samples were vacuumfiltered through $0.45 \mu \mathrm{m}$ filters (Gelman Metricel) in the ficld. Although the filters were not pre-wcighed, variability between blank filters amounted to just $\pm 1.2 \mathrm{mg}(1.6 \%)$. Seven aliquots were collected within a period of $1 \mathrm{~min}$ on 20 Junc to test reproducibility; the mean and standard-deviation concentration of these was $2223 \pm 54 \mathrm{mg} \mathrm{L}^{-1}$.

The suspended-sediment rating curve (Fig. 4) is nearly linear over much of its range, but this relationship falls off at turbidity readings of $>1500 \mathrm{mV}$. To be conservative, wc used the exponential fit shown in Figure 4, which is similar to the empirical fit used by Humphrey and others (1986). The turbidity sensor readings were pinned at the top of its range, $2500 \mathrm{mV}$, during the peak discharges of the spring flood; calculated concentrations during these times thereforc are likcly to underestimate the suspended-sediment concentration.

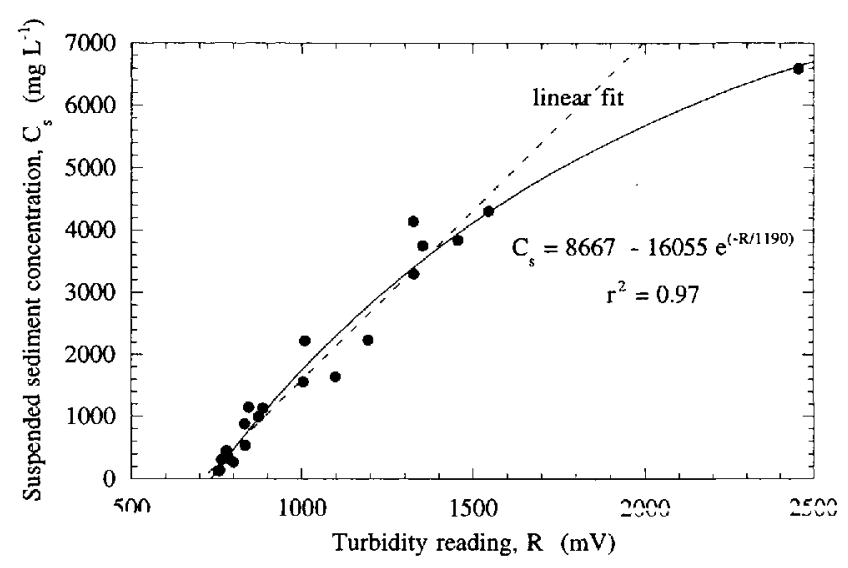

Fig. 4. Suspended-sediment rating curee. Uppermost data point is close lo lurbidity-sensor saluration value of $2500 \mathrm{mV}$. The exponential fit was adopted for suspended-sediment calculations because it is more conservatize at high turbidily readings than the linear curve shown.

The turbidity sensor is attached to the base of the PVC floats, and is therefore very near the surface of the flow, where sediment grain-sizc and concentration are at a minimum. In order to assess the degree to which this measurement underestimates the mean concentration, we measured one scdiment-concentration profile (Fig. 5), collected on 20 June by attaching four bottles to a dowel. For suspended-sediment transport, one expects (e.g. Rousc, 1937) a power-law relationship between concentration, $C$, and depth, $z$, i.e. $C=C_{\mathrm{a}}\left(z / z_{\mathrm{h}}\right)^{p}$, where $C_{\mathrm{a}}$ is the mcasurcd concentration at a reference height $z_{\mathrm{a}}$ above the bed, and the exponent is the Rouse number, $p=w /\left(k u^{*}\right)$, where $w$ is the scttling velocity of the grains in suspension, $k$ is von Kármán's constant $(0.4)$ and $u^{*}$ is the shear velocity of the flow $\left((g H S)^{1 / 2}\right.$, where $H$ is flow depth and $S$ is channel 


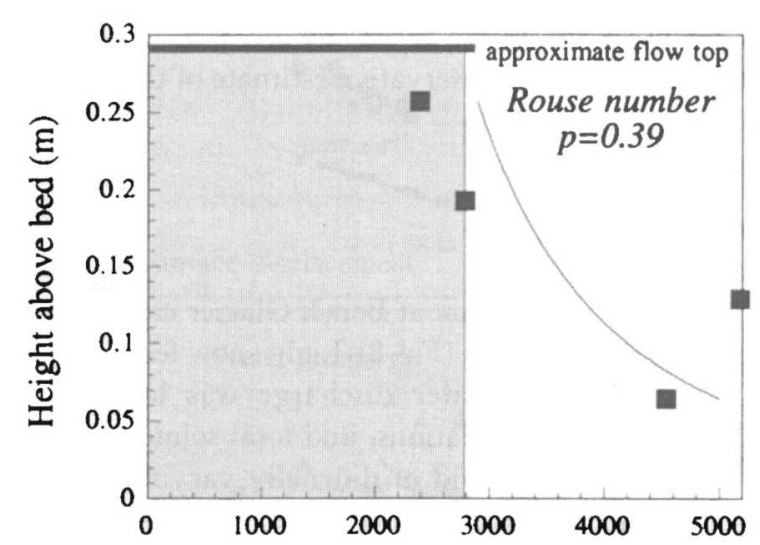

Suspended sediment concentration $\left(\mathrm{mg} \mathrm{L}^{-1}\right)$

Fig. 5. Suspended-sediment concentration profile showing strong concentration gradient within the flow. Samples taken from a sampling rod to which four bottles were attached at regular intervals, all opened to the flow once the rod was in place. A simple power lawe fits the data well, with a Rouse number of 0.39. The signal derived from the turbidity sensor in the surface water, with a concentralion represented by the gray box, will likely underestimate the mean concentration by several tens of per cent.

slope). The sediment concentration indecd increases significantly with depth (Fig. 5), and the profile may be approximated by a power law with exponent -0.39 . For the local slope of the channcl $(0.04)$, and instantaneous flow depth of $0.29 \mathrm{~m}$, we expect $u^{*}=0.31 \mathrm{~m} \mathrm{~s}^{-1}$. Solving for settling velocity from the Rouse number, $w=p k u^{*}$, we find that the settling velocity of the sediment dominating the concentration profile is $0.05 \mathrm{~m} \mathrm{~s}^{-1}$. From seltling-velocity relationships (e.g. Dietrich, 1982), this corrcsponds to quartz grains of diameter roughly $10^{-4} \mathrm{~m}$, or coarse silt, a reasonable prediction for the dominant scdiment in suspension in this glacial river. The ratio of the surface concentration, $C_{s}$, to the mean (vertically averagcd) concentration, $\bar{C}$, is

$$
\frac{C_{\mathrm{s}}}{\overline{\bar{C}}}=(-p+1)\left[\frac{1-z_{\mathrm{a}} / H}{1-\left(z_{\mathrm{a}} / H\right)^{-p+1}}\right] .
$$

For our case, with $\mathrm{P}=0.39$, Equation (2) suggests that this ratio should be 0.8 , meaning that by measuring the surface concentration, our measurements reflect roughly $80 \%$ of the mean suspended-sediment concentration. We have not corrected our suspended-sediment concentrations, calculated from our turbidity time serics, for this effect. Nor have we quantified transport by bedload, which can be up to $50 \%$ of the sediment discharge by a glacial stream (Church and Gilbert, 1975; Ostrcm, 1975; Hammer and Smith, 1983; Gomez, 1987) and is not treated by the suspended-sediment transport analysis above. Rather, the surface concentration wc use to constrain the mean concentration should be considered lower-bound estimates.

\section{Solutes}

Following Gurncll and others (1994), we sampled water during daily high and low flows, and densified these records temporally with electrical conductivity recordcd cvery 15 minutes at the stream gauge. Twice-daily water samples were filtered, usually within 3 hours, into pre-washed highdensity polyethylene bottles that werc rinsed with filtered sample. Onc-half of each sample was acidified with ultrapure nitric acid. The longest time beforc any of the samples was filtered was 13 hours. An experiment in which seven Bench River samples werc collected simultancously and stored for varying timcs before filtration showed a $2.4 \%$ increase in the total dissolved solids (TDS) in samples stored up to 14 hours, relative to the sample filtered within 4 min of collection, and an $8 \%$ increase in TDS of samples stored up to 100 hours.

We measured $\mathrm{pH}$ in the field by placing the electrode of a portable meter (Triple Check) directly into the river watcr. The $\mathrm{pH}$ was slow to equilibrate in the $\sim 1^{\circ} \mathrm{C}$ water, often taking as long as $20 \mathrm{~min}$. The filtered samples were analyzed in the laboratory, using a Dionex DXI00 ion chromatograph for anions, a Finnigan Element high-resolution inductively coupled plasma mass spectrometer (ICP-MS) for cations, a Lachat QuikChem 4000 autoanalyzer for silica, and an automated titrator for alkalinity (Gran method, titrating with $\mathrm{HCl}$ to a $\mathrm{pH}$ of 3.5 ). The charge balance,

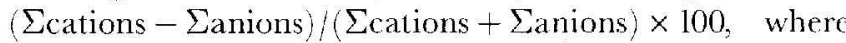
concentrations are reported in eq $\mathrm{L}^{-1}$, on these samples averaged $-1.6 \pm 2.8 \%$. Analysis of replicate samples and repeated analysis of the same sample yield analytical uncertainties of $0.5 \%$

We calculate the partial pressure of $\mathrm{CO}_{2}$ with which the water is in equilibrium, or $\mathrm{PCO}_{2}$ as follows:

$$
\log P_{\mathrm{CO}_{2}}=\log \left\{\frac{\left[\mathrm{HCO}_{3}^{-}\right]\left[\mathrm{H}^{+}\right]}{K_{\mathrm{H}} K_{1}}\right\}
$$

where the concentration of $\mathrm{HCO}_{3}{ }^{-}$is in mol L ',$K_{\mathrm{IJ}}=10^{1.11}$ mol atm ${ }^{-1}$, and $K_{1}=10^{-6.58} \mathrm{~mol} \mathrm{~L}^{1}$ at $0^{\circ} \mathrm{C}$ (Drever, 1997).

Electrical conductivity depends on the concentration of charged species in the water (Hem, 1982). We convert conductance measured at the stream gaugc (recorded as a resistivity) to TDS using the exponential rating curve shown in Figure 6 to obtain a detailed time series of solute concentrations.

\section{Snowmelt and air temperature}

We measured ablation several times per day using wooden snow stakes at four locations within a roughly $200 \mathrm{~m}$ radius of the survey station location, below the terminus of the glacier. The mcasurements are thercfore most relevant to the lower kilometer of the glacier. Stake locations were changed slightly at the time of each mcasurcment to mini-

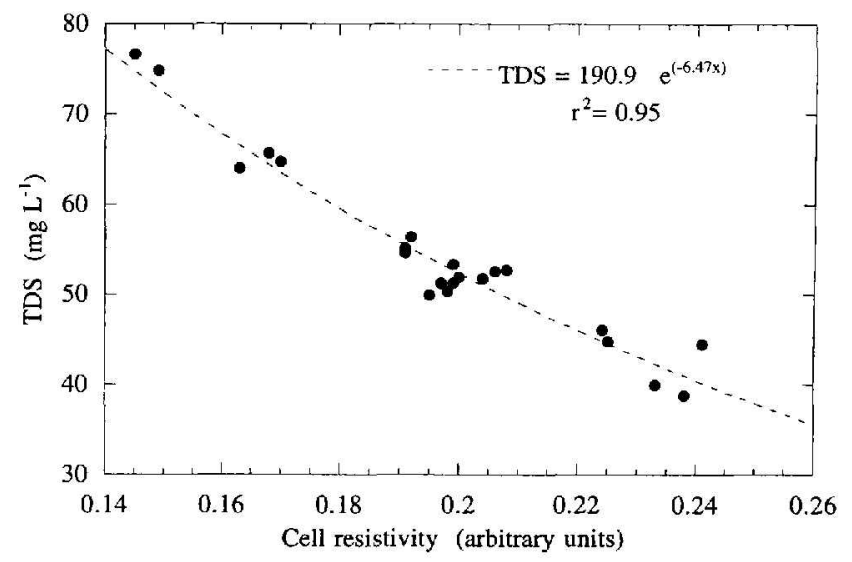

Fig. 6. Rating curve for TDS and electrical conductivity (measured as a resistivity in the stream-gauge instrumentation). TDS here is the sum of cations $\left(\mathrm{Ca}^{2+}, \mathrm{Mg}^{2+}, \mathrm{Na}^{+}\right.$ and $\mathrm{K}^{+}$), anions ( $\mathrm{HCO}_{3}{ }^{-}, \mathrm{SO}_{4}{ }^{2-}, \mathrm{NO}_{3}^{-}$and $\mathrm{Cl}$ ), and sili$c a$ in the form $\mathrm{SiO}_{2}$ all measured in $m g L^{\prime}$. 
mize growth of ablation cones. Snow density was measured at only a few locations; we convert the lowering of snow thickness to loss of water equivalent using the mean measured density of $490 \mathrm{~kg} \mathrm{~m}^{3}$. In addition to the snowmelt measurements, ice ablation was cstimated by the emergence from the glacier surface of the drill rods on which the triple reflectors were mounted.

We use the positive degree-day (PDD) approach (e.g. Braithwaite and Olesen, 1989; Braithwaite, 1995) to densify these measurements temporally and to extend them areally to estimate the snowmelt rate on the entire glacier. The PDD approach relates the icc- or snowmelt in a given period of time (usually a day) to the air temperature, in number of degrees above $0^{\circ} \mathrm{C}$, for that period (i.e. melt $=\gamma T$ for $T>0^{\circ} \mathrm{C}$ and melt $=0$ for $T<0^{\circ} \mathrm{C}$ ). To calibrate the factor, $\gamma$, in the PDD calculation, we use the temperature measured in the stream-gauge data-logger box at 15 min intervals. We plot the temporal integral of the box-temperature time series, using the time unit of days, and the cumulative snowmelt water equivalent for each of our ablation stakes, as functions of time (Fig. 7). The model curve, representing the product of a specificd $\gamma$ and the temperature history, can bc made to match the snowmelt data well using $\gamma=$ $3.1 \mathrm{mmd}{ }^{10} \mathrm{C}^{1}$ (curve labeled 0 ). While this is at the low cnd of the range reported by Braithwaite (1995) in his summary of existing snowmelt datasets, this can be explained by the fact that the temperature of the cxposed gray box is typically higher during the daytime than the local air temperature. (A $\gamma$ of $4.3 \mathrm{mmd}{ }^{1}{ }^{\circ} \mathrm{C}^{1}$ obtained from a short airtemperature time series was not used, because the data-logger box temperature has the longer time series.) The best constant- $\gamma$ model of snowmelt bcgins to underestimate the snowmelt rate late in the study. This is likely due to a reduction in the albedo of snowpack with age, which should therefore increase $\gamma$ toward that of pure ice (roughly two times greater than for snow; Braithwaite, 1995). We illustrate this effect with simulations in which $\gamma$ is allowed to rise linearly through the study period at a specified rate (curves labeled 2, 4 and 6 in Fig. 7). As snow over the glacier probably did not ripen to the extent seen in our ablation-stake

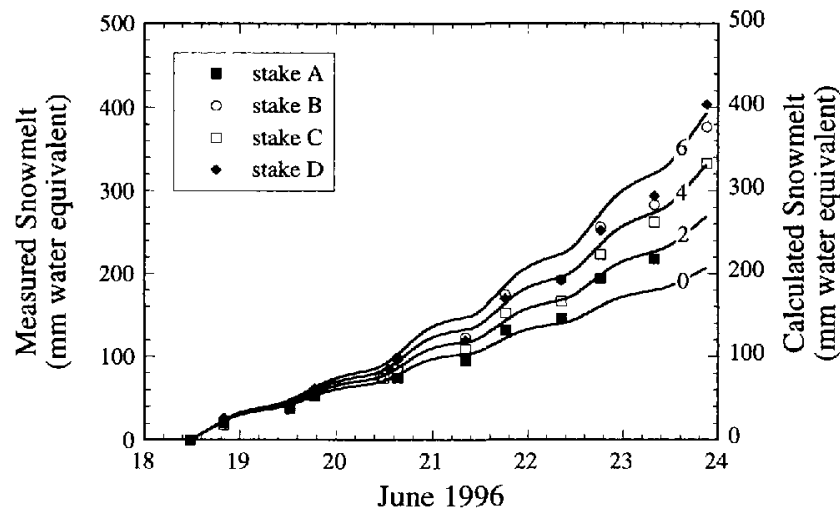

Fig. 7. Calibration of snowmelt against air-temperature time series to constrain the PDD factor, $\gamma$. Spot measurements of snow elevation at four locations are converted to loss of water equivalent using a nominal snow density of $490 \mathrm{~kg} \mathrm{~m}^{-3}$. Continuous lines represent integrals of the melt through time, calculated from air temperature multiplied by the PDD factor that best fits the rate of snowmelt, here $3.1 \mathrm{~mm} d^{1}{ }^{\circ} \mathrm{C}^{\prime}$.' Maturation of the snow accounts for growing rate of melt through time, and is modeled here with linear growth of the $P D D$ factor at rates of $0-6$ per week (labeled on the curves). array, we use a constant $\gamma=3.1 \mathrm{~mm} \mathrm{~d}^{1}{ }^{\circ} \mathrm{C}{ }^{1}$. Ignoring this effect will result in a conservative estimate of the snowmelt input to the glacier.

\section{RESULTS}

Our 16 days of observation at Bench Glacicr can be broken into four distinct periods (Fig. 8). Light snow fell on the first 3 days; consequently water discharge was low and not marked by diurnal oscillations, and total solute concentrations were high. A period of diurnally varying discharge and solute concentration ensucd undcr clcar skics starting on 15 June. Ice-surface velocity averaged nearly $0.1 \mathrm{md}$, although, as discussed below, this too was marked by diurnal oscillations. During 22-24 June the diurnal pattern of discharge broke down despite continued clear weather, the ice-surface velocity nearly doubled, and suspended-scdiment concentration rosc dramatically to a peak late on 24 June. This period of high ice velocity, high discharge and high suspended-sediment flux ended with a rapid increase in water discharge late on 24 June; thereafter, the ice vclocity returned to pre-22 Junc bchavior but with a lower mean and lower diurnal variability, and solute concentrations no longer varied diurnally. We consider the occurrences on 22-24 June to be a spring spccd-up and flood event, although its effects clearly continue for the remaining 3 days of observations. The chief characteristics of this cvent are (i) a loss or decrease in diurnal discharge oscillations, (ii) an increase in sliding vclocity at our measurement sites, (iii) high suspended-sediment concentration, particularly at the end of the event and during its culminating flood, and (iv) sustained high solute concentrations after the flood event. Below, we discuss the pre-event conditions, the event, and conditions after the event in turn.

\section{Pre-event conditions}

During the clear weather of 15-22 June, the water discharge (Fig. 8b) settled into a diurnally varying pattern. The amplitude of these discharge swings grew through this period, from 1.5 to $3.5 \mathrm{~m}^{3} \mathrm{~s}$, while the mean daily discharge grew from 1.8 to $4.8 \mathrm{~m}^{3} \mathrm{~s}^{-1}$. The average ice-surface specd during this time was $97 \mathrm{~mm} \mathrm{~d}^{-1}$, but on closer inspection, strong diurnal variations can be seen (Fig. 9).

\section{Sliding speeds}

The records of distances to the two targets are shown in Figure 8a. As the errors associated with the lower target are considerably smaller than those of the upper target, we focus here on this lower displaccment record. We analyzed the data in three distinct segments (Fig. 9). The curve fits are based upon the assumption that the surface speed is composed of a steady component associated with internal deformation, $U_{\mathrm{d}}$, and a diurnally fluctuating component associated with sliding. Although one could choose any of many periodic functions for the oscillating component, we have chosen to use a simple sinusoidal function, the primary goal being to assess the amplitude and the phase of the fluctuations:

$$
U(t)=U_{\mathrm{d}}+\left[\overline{U_{\mathrm{s}}}+\Delta U_{\mathrm{s}} \sin \frac{2 \pi(t-\tau)}{P}\right]
$$




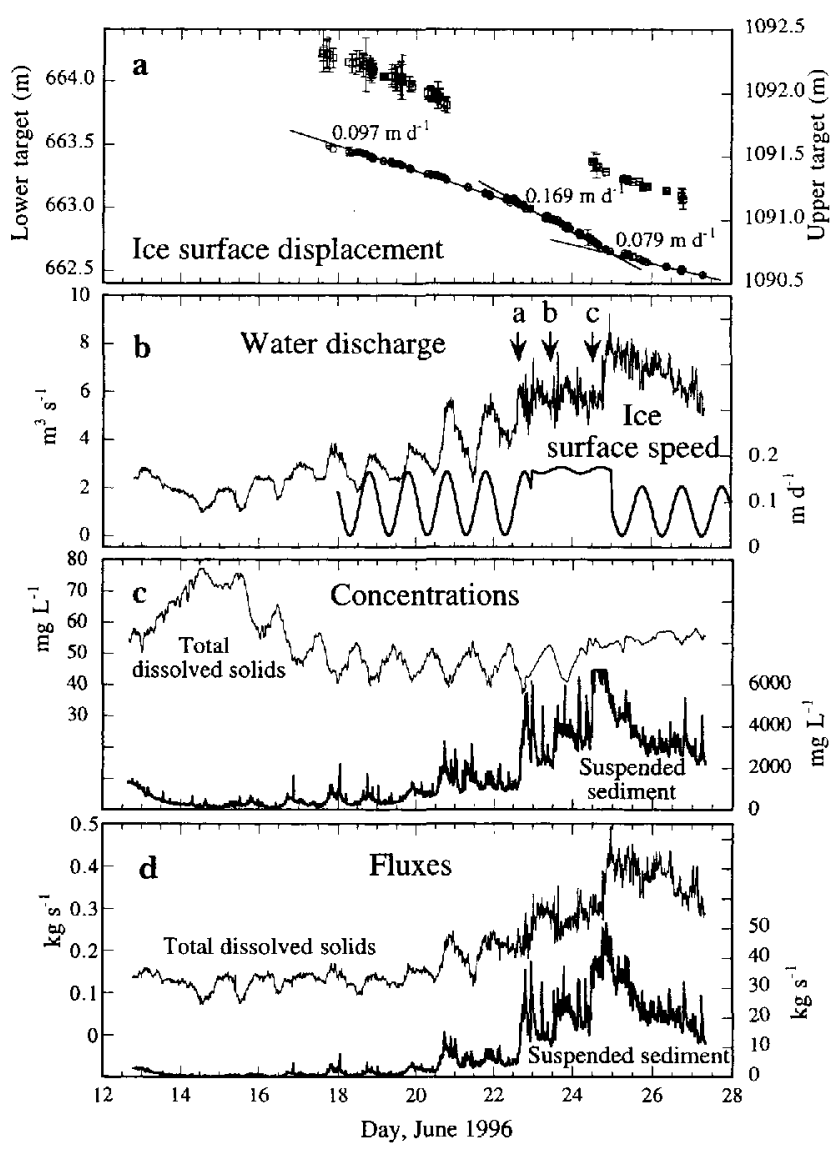

Fig. 8. Summary of Bench Glacier time series. (a) Displacement record for two reflectors over the 10 days of the electronic distance meter (EDM) record. Scales for the two targets are identical. Error bars denote instrumental standard deviations

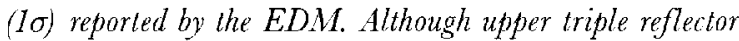
(open squares) yielded much larger errors associated with almost double the distance to the reflector, the correspondence between the two records indicates similar three-part history of molion. Numbers indicate mean daily speed al lower larget, derived from slopes of linear fits through the displacement history. (b) Water discharge and ice-surface velocity. The latter record is derived from modeling short segments of the displacement time series (Fig. 9). The three periods display distinctly different behaviors. In both the pre-and post-speed-up segments, the speed varies strongly each day, but achieves the same minimum, presumably associated with internal deformation. Speed-up is associaled with loss of the strong variation, and is pinned at roughly the highest pre-speed-up velocity. The $\sim 20 \%$ reduction in the post-speed-up velocity is associated with lowering of the maximum speed. Arrowes show timing of the following observations: a, high flow destroys the cable support system for tethered fish at gauging station; b, numerous ice chunks, up to $0.5 \mathrm{~m}$ in diameter, appear in the stream; $c$, dirty water observed emerging from small crevasses on the glacier surface near the terminus. (c) Concentrations of suspended sediment and TDS. (d) Chemical and suspendedsediment fluxes from Bench Glacier.

The displacement record is simply the integral of the velocity, or

$$
D(t)=D_{0}-\left[\left(U_{\mathrm{d}}+\overline{U_{\mathrm{s}}}\right) t+\Delta U_{\mathrm{s}} \frac{P}{2 \pi} \cos \frac{2 \pi(t-\tau)}{P}\right]
$$

where $D_{0}$ is the initial distance to the target, $\overline{U_{\mathrm{s}}}$ is the mcan sliding speed, $\Delta U_{\mathrm{s}}$ is the half-amplitude of the speed fluctuation, $P$ is the period of the fluctuation (here set to 1 day)

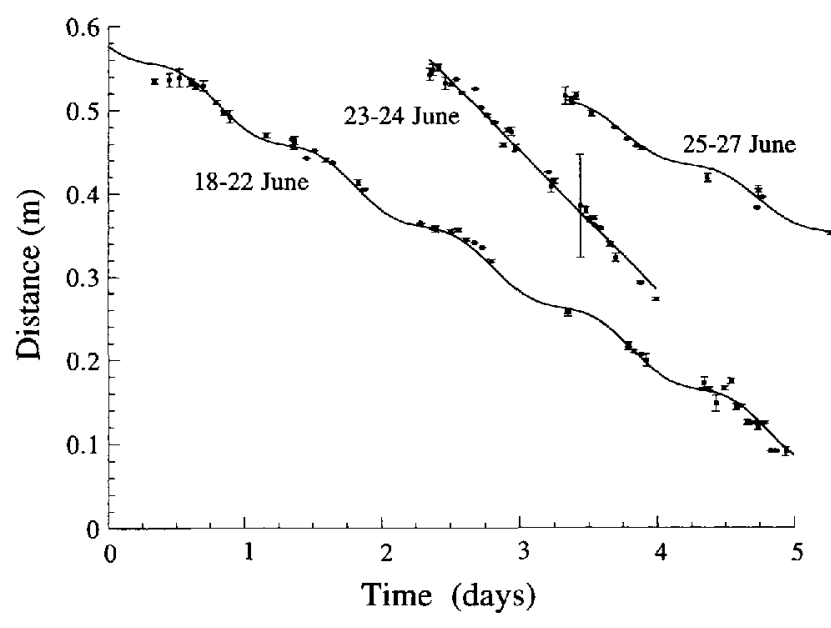

Fig. 9. Details of displacement records for lower target on ice, fil by the integral of a sinusoidally varying velocity history (see text). Error bars denote instrumental standard devia-

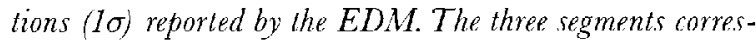
pond to the three straight-line segments shown in Figure $8 a$. For each segment, midnight corresponds 10 major tick marks. Ice-surface speeds shown in Figure 86 are the derivatives of the curves shown here. Although night-time measurements are sparse, the high amplitude variation in slope requires significanl variations in speed in the 18-22 June and 25-27 June segments.

and $\tau$ is the lag relative to midnight $(t=0)$. Inspection of Figure 9 shows that a sinusoidal fluctuation in velocity captures the essence of the displacement rccords for each of the three data segments. In cach casc, we fit for all parameters of the velocity history except for the period. The combined modeled velocity record is shown in Figure 8 b. Crudely, we intcrpret the low minimum velocity to be that associated with internal deformation; this is attained in both pre- and post-specd-up intervals.

As shown in Figure 8b, the speed fluctuations are well correlated with dischargc fluctuations, as expected if sliding rates are indeed modulated by some aspect of the hydrologic system. Here the speed reaches a maximum in concert with the discharge maximum at $\sim 1800-1900 \mathrm{~h}$. We have less confidence in the correspondence of the minima, as the earlymorning surface speeds are less well constraincd.

\section{The spring event}

On 22 June and for the next 2 days, the amplitudes of the discharge and sliding-speed diurnal variations decreased while the means increased to a level comparable to the peak values of the previous days. 'This gives the appearance of an abrupt loss of oscillatory character in these parameters (Fig. 8b). This period of sustained high discharge and ice velocity was accompanied by large increases in the concentration of suspended sediment (Fig. 8c). The sediment shows pcaks roughly centcred around $1800 \mathrm{~h}$, a time when water discharge from snowmelt should reach a maximum for the day. Solute concentrations remain oscillatory through this period, with no change in amplitude or mean.

The sediment discharge is plotted in Figure $8 \mathrm{~d}$. The sediment removed in suspension over the course of the large peak in sediment discharge is greater than the total suspended-sediment flux in the 10 days prior to this cvent. The maximum discharge of $40 \mathrm{~kg} \mathrm{~s}^{-1}$ is large for the scale of the 
glacier, corresponding to $48 \mathrm{mma}^{-1}$ of lowering of the glacier bed if sustained for an entire year.

We have anecdotal evidence of substantial subglacial hydrologic reorganization during this period. On 23 June we noticed a number of large (up to $0.5 \mathrm{~m}$ diameter) ice chunks in the outlet stream. As not even minor collapse of ice at the outlet portal was observed, these chunks must have been derived subglacially. At about noon on 24 June, one of us (R.S.A.) traversing the glacier between the lower triple reflector and the ice margin heard numerous sounds coming from within the ice, and encountered a turbid stream flowing on the ice as it emerged from a thin crevasse. Presumably, high water pressures within the glacier forced this turbid water to the surface from the bed.

The spring event terminated late on 24 June with a step increase in the discharge of $\sim 3 \mathrm{~m}^{3} \mathrm{~s}^{-1}$, or $50 \%$, in 4 hours, accompanied by the highest observed suspended-sediment concentrations. As our turbidity sensor was saturated during this period, the sediment concentrations and fluxes in Figure 8 represent minimum estimates.

\section{Post-event conditions}

The period after the discharge peak on 24 June differs in character from both the event and the pre-cvent period (Fig. 8). Discharge fell slowly after its sharp culmination, with no cvidence of diurnal oscillation. Ice-surface speed, however, returned abruptly to a lower average rate. Sediment concentrations fell dramatically. The one record that does not show a relaxation following the heightened activity of the spring event is that of solute concentrations. The steady diurnal oscillations of TDS (Fig. 8c), maintained before and during the event, disappear on 24 June, to be replaced with a period of steady, high concentrations. Because the TDS remains high after the termination of the event, the solute flux remains high after 24 June, instead of falling as the suspended-sediment flux docs (Fig. 8d).

It is likely that the channel cross-section at the streamgauge sitc varicd through the flood cvent. The necd to reset our discharge rating curve because of apparent aggradation on 26 June suggest that a wave of coarse sediment may have reached our gauging site at that time, lagging behind the documented pulse of suspended sediment on 2425 June. Warburton (1992) observed a wave of aggradation that propayated down the Bas Glacier d'Arolla (Swiss Alps) outlet stream following scour in a large flood. It seems likely that the aggradation we infer on 26 June was of this nature, although there is no indication of scour during the flood, cither at our gauging sitc or upstream.

\section{DISGUSSION}

We believe that the specd-up and flood cvent of 22-24.Junc represents the build-up of subglacial water pressure near the terminus in a dominantly distributed flow system, and subsequent release of pressure and reduction in sliding specd due to extension or formation of one or more subglacial conduits. High sliding velocity and high water discharge arc strongly correlated both before and during the event. If sliding velocity is modulated by basal water pressures, then this correspondence suggests that the water discharge can be uscd as a proxy for subglacial water pressures near the terminus. The observation of turbid water spilling onto the glacier surface on 24 June indicates at least locally high subglacial water pressures during the event. The suspended-sediment flux associated with this event likely represents cvacuation of stored scdiment by turbulent water flow accessing new parts of the bed (Willis and others, 1996), suggesting either that new conduits formed or that existing conduits migrated. The large ice chunks spewed out during the event support the former interpretation.

The important question is what triggered this transition in the subglacial drainage system. A storm did not precipitate the event; although light rain fell a few hours before the culminating flood, none fell in the 9 days before the event. We examine below the water balance for the glacier during this time interval in an attempt to quantify the timing and magnitude of changes in storage of water subglacially.

\section{Water inputs to the glacier from melt}

Given the locally calibrated relation betwecn air temperature and snowmelt water equivalent, we generate a time series of water inputs to the glacier. The calculation is based on an assumption that there was no sublimation or loss of snow or ice mass by any process other than surface molting, and that the only source of liquid water was melt due to incoming solar radiation. As the positive degree-day factor $\gamma$ is about two times greater for ice than snow (Braithwaitc, 1995), we must also constrain the evolution of the fraction of the glacier that was bare ice through the short period of our study. These constraints come from two observations of the glacier surface from the air, on our incoming $(0 \%$ exposed ice) and outgoing (30\% exposed ice) flights. We assume a linear variation of the exposed ice fraction, $f_{\text {ice }}$, from 0.0 to 0.3 over the 16 day study period. Wc also calculate the snowmelt from the non-glacierized portion $(28 \%)$ of the catchment. The fraction of this area that is exposcd rock on the valley walls, $f_{\text {rock, }}$ increascd from roughly $30 \%$ to $80 \%$ over the study period; we assume this too increases linearly. Although, as discussed above, we are aware that the albedo of snow declines considerably as it ripens, incorporation of this effect is unwarranted given the other errors in our data. We seek a conservative estimate of snowmelt water equivalent from the basin.

The rcsulting summed snow- and icc-mclt watcr inputs, $Q_{\text {in }}(t)$, to the glacial system are therefore determined through

$$
\begin{aligned}
Q_{\text {inl }}(t)= & A_{\mathrm{g}}\left[\left(1-f_{\text {ice }}\right) \gamma_{\text {snow }} \bar{T}_{\text {snow }}+f_{\text {ice }} \gamma_{\text {ice }} \bar{T}_{\text {ice }}\right] \\
& +\left(A_{\mathrm{b}}-A_{\mathrm{g}}\right)\left[\left(1-f_{\text {rock }}\right) \gamma_{\text {snow }} \bar{T}_{\text {ng.snow }}\right]
\end{aligned}
$$

where $\gamma$ is the PDD factor (here we take $\gamma_{\mathrm{s} 10 \mathrm{w}}=3.1 \mathrm{~mm}$ $\mathrm{d}^{1}{ }^{\circ} \mathrm{C}^{1}$ and $\left.\gamma_{\text {icc }}=6.2 \mathrm{~mm} \mathrm{~d}^{-1} \mathrm{C}^{-1}\right), A_{\mathrm{b}}$ is the total area of the basin, and $A_{\mathrm{g}}$ is the area of the glacier. All temperatures are mean temperatures of those portions of the catchment, calculated using the data-logger box temperature and an assumed lapse rate of $6.5^{\circ} \mathrm{C} \mathrm{km}$. The first term corresponds to melt production from the glacier, the second to melt production from the non-glacierized part of the catchment. The result of this calculation is plotted in Figurc 10. The integrated melt varies by many-fold daily, with a range over the study period of essentially 0 (freezing nights) to $\sim 10 \mathrm{~m}^{3} \mathrm{~s}^{-1}$. While the contributions of water from snowmelt show a general decline, those from ice melt generally increase through the study period. The non-glacierized part of the catchment contributes minimally $\left(<\mathrm{m} \mathrm{m}^{3} \mathrm{~s}^{-1}\right)$ and declines through time as snowmelt exposes bare rock. Given the lack of significant rain over most of the period (until 24 


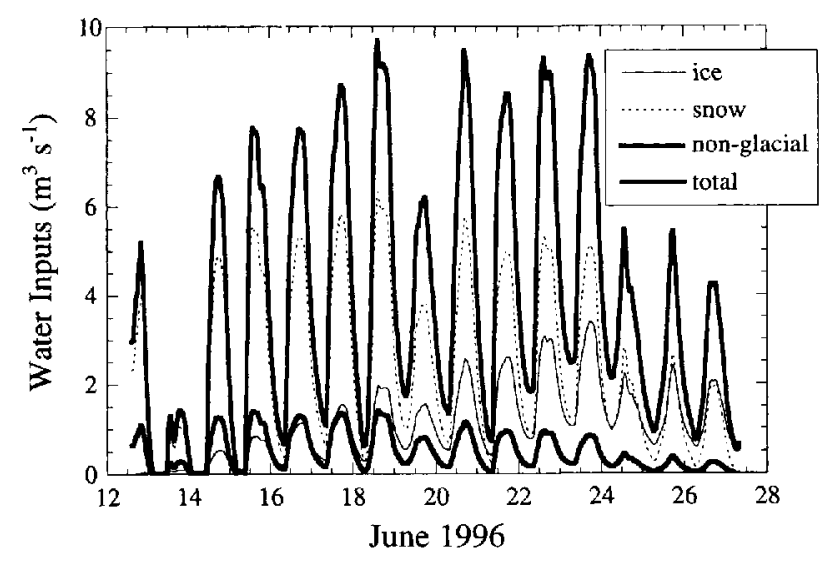

Fig. 10. Calculated meltwater production using Equation (6). The melt production includes contributions from snowmelt in upper catchment and from ice melt in lower catchment, and snowmell from the non-glacierized part of the catchment. Proportion of glacier with exposed ice varies linearly from 0 to $30 \%$, while proportion of non-glacierized catchment with bare rock varies from $30 \%$ to $80 \%$ over the measurement interval. The fraction of the flow atiributable to ice melt grows through time, while that associated with snowmelt on both glacier and non-glacier parls of the catchment declines. Maximum contribution from non-glacierized catchment is roughly. $10 \%$.

June), the solar-radiation-driven melt shown in Figure 10 represents the primary source of water to the glacier. Cloudiness on 19 June lowered the melt maximum, while on 24 June a storm system began delivering light rain, lowcring significantly the expected melt rate.

\section{Water inputs, outputs and changes in storage}

The calculated snow- and ice-melt inputs and the measured outputs are plotted together in Figure 1l. Although the input side of the water balance is only roughly constraincd, the order of magnitude and liming of melt must be correct. Several fcatures of the curves are important. First, the amplitude of the variations in the melt inputs is significantly greater than that of the discharge from the glacier. Peak mclt production approaches $10 \mathrm{~m}^{3} \mathrm{~s}$, whilc peak discharge before the flood event is no more than about $6 \mathrm{~m}^{3} \mathrm{~s}^{-1}$. Conditions on 12-14 Junc were cold and snowy, and melt production fell to zero overnight, while discharge declined. Second, while there is always a lag between melt input and stream discharge, this lag decreases steadily before and through the event from 6 hours to 2.75 hours (Fig. 11b), possibly reflecting an increase in efficiency of the subglacial hydrologic system. The ncarly 10 hour lag at the culmination of the event on 24 June shows that this flood was unrelated to diurnal melt variations, and suggests that instead it represents the establishment of a different drainage route. Third, before the event, the mean daily rate of input to the system is consistently greater than the mean daily discharge from the system. In the clear-weather pre-event period (15-22 June), inputs avcragc $4.5 \mathrm{~m}^{3} \mathrm{~s}^{1}$, while daily discharge averages $2.9 \mathrm{~m}^{3} \mathrm{~s}^{-1}$. This relationship changes abruptly after 22 June. For 2 days, inputs and outputs were roughly equivalent, and starting 24 June, outputs cxcceded inputs.

The water balance is further illustrated in Figure 1lc, in which we plot the cumulative snow- and ice-melt inputs, the cumulative water outputs and the implied history of storagc.
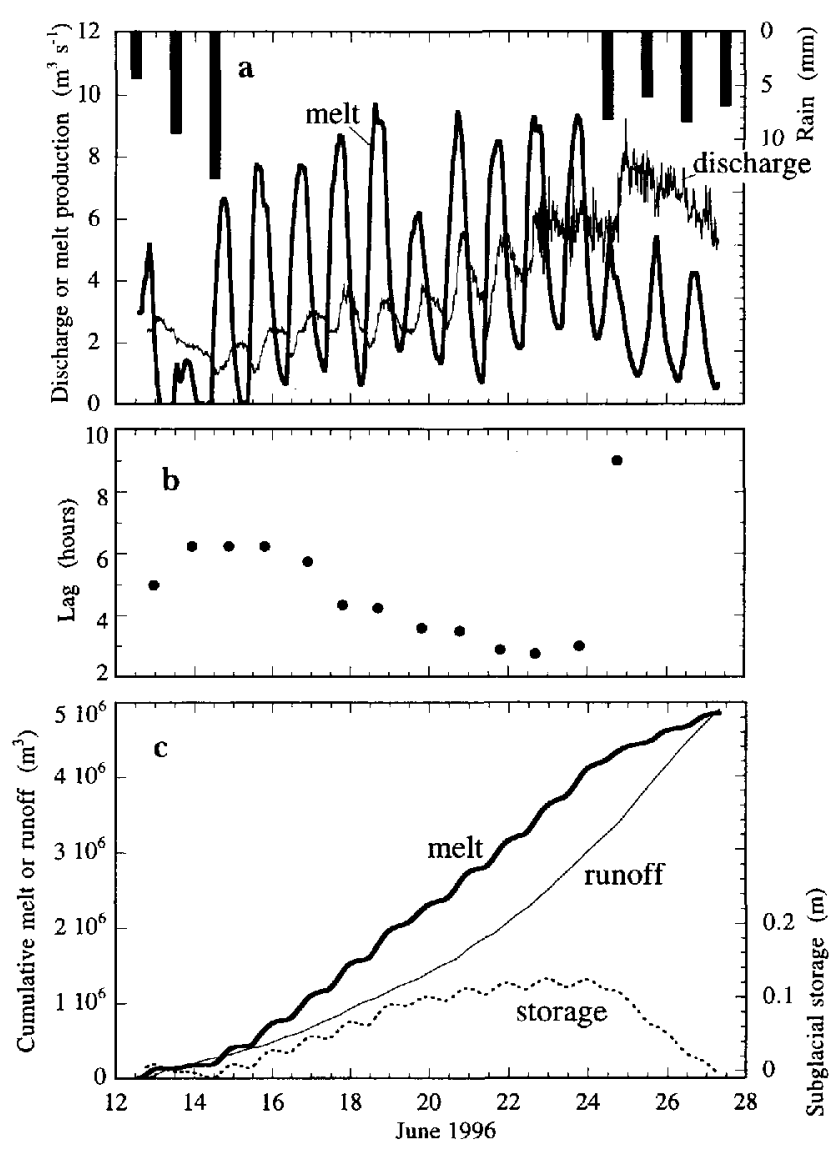

Fig. 11. (a) Water inpuls and outputs from Bench Glacier through the 16 day observation period. Rain measured in Valdez, $25 \mathrm{~km}$ west, correlates with changes in melt, but is insufficient to aller greally the net inputs to the glacier. Unitl 24 Fune, mean daily runoff is less than mean daily melt production, implying net englacial storage. (b) Lag between maximum calculated meltwater production and measured peak discharge. The lime-scale of the lag declines from 6 hours to 2 hours by the time of the flood on 24 . June. (c) Cumulative melt production and runoff through the period of observations. The difference between these curves is subglacial storage of weater, here normalized to the $9 \mathrm{~km}^{2}$ area of the glacier.

The storage is calculated as (inputs - outputs)/area of glacicr, and is therefore in units of $m$ w.e. within the glacier, and includes water stored within snow and firn. We recognize that this calculation compounds the errors in our discharge measurements and melt calculations. We present the results because the pattern we obtained, without manipulation, displays intercsting parallels with other, more robust observations. The pre-event period is characterized by inputs in excess of outputs, and accumulation of water in storagc. The calculated storage stabilized at a value of roughly $0.13 \mathrm{~m}$ on 22 June, the time when the diurnal discharge variations diminished. Interestingly, it appears that the cumulative discharge in the flood was sufficient to drain a significant fraction of the water stored within the glacier from the early melt scason. Recalling that the snowmelt calculations led to conservative estimates, the apparent drawdown of storage to zero at the end of the observation period is fortuitous. Iken and others (1983) observed surface uplifts, attributed to water storage, of up to $0.2 \mathrm{~m}$ over periods of a few days at Unteraargletscher, in keeping with the magnitude of water storage calculated here. More careful estimation of water storage within a glacier could lead to greater insight into the connections between sliding and storage; 
this would be best achicved with better characterization of melt inputs over the entire glacier.

The decline in lag between melt production and runoff peaks is indicative of a drainage system that is increasingly efficient at delivering water to the stream. Certainly, part of this cfficiency gain comes from increasing areas of bare ice that rapidly transmit melt into crevasses and moulins. However, the greater than two-fold drop in lag time scen over the course of this study is much greater than the $\sim 30 \%$ increase in exposed ice surface on the glacier. Some of this increased efficiency must derive from greater connectivity of cavities in the days preceding the flood event. The growth in pcak discharge in the pre-event period, despite relatively constant inputs, also speaks to more cfficient delivery of water through the subglacial system. Despite the increasing efficiency of the subglacial hydrologic system, the calculated storage continued to increase. It is this backing-up of water in the system that presumably leads to increased basal water pressures and sustained sliding.

The mismatch between discharge outputs of water and meltwater inputs is just balanced at the beginning of the speed-up event on 22 June. The storage had increascd slowly to slightly more than $0.1 \mathrm{~m}$, averaged over the entire glacier bed, at the beginning of the speed-up, and then "stabilized" over the next 2 days. During this period of near-parity between discharge and meltwater inputs, ice chunks in the outlet stream and sounds emitting from the glacier suggest to us that significant rearrangement, presumably enlargement, of subglacial conduits was occurring. The ultimate flood on 24 June, during a period of declining meltwater inputs, appears to represent the final push in establishing a subglacial drainage system capable of draining the accumulated meltwater. Its timing is unrelated to diurnal meltwater inputs, and the discharge thereafter is in excess of inputs.

\section{Runoff chemistry}

Beforc 24 June, the concentrations of dissolved solutes in the runoff varied inversely with discharge each day (Figs $8 \mathrm{c}$ and 12). These diurnal variations are normal in glacicrs, and arise from variations in the pathways by which water reaches the outlet (Collins, 1979; Tranter and Raiswell, 1991; Tranter and others, 1993), and variations in the contact time of water with subglacial scdiments (Collins, 1995; Brown and others, 1996a). Low solute concentrations are associated with high fluxes of dilute supraglacial meltwaters that have travelled rapidly through the glacier with minimal interaction with the bed, while high solute concentrations are found in water that has had intimatc contact with the glacier bed.

The simple inversc rclationship between TDS and discharge broke down during the speed-up and flood event. Diurnal oscillations in TDS continued at the same amplitude through the specd-up cvent, despite a reduction in the amplitude of discharge variations; the TDS oscillations disappear in the flood culminating the spring event, and remain suppressed for the remaining 3 days of observation (Fig. 8c). These changes yield three classes of behavior on a plot of TDS concentration as a function of discharge (Fig. 12). Before the speed-up and flood event, concentrations vary inversely with discharge. On 22-24 Junc, discharge variations declined, but TDS oscillations continucd, resulting in a lack of correlation between these parameters. The post-event (post-24 June flood) data plot as a horizontal

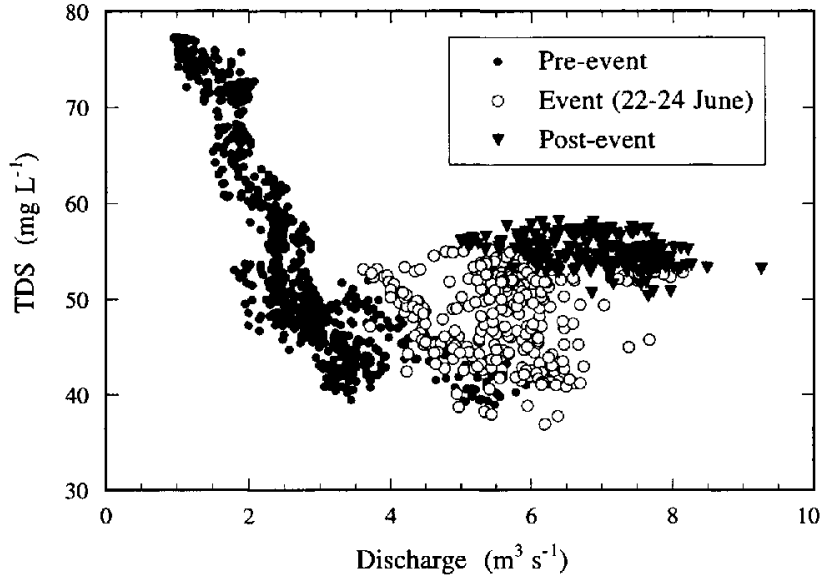

Fig. 12. The relationship between solute concentrations (as measured by TDS calculated from conductivity) and discharge in the Bench River can be broken into three dislinct behaviors. The pre-event period (up to 22 June) is marked by a strong inverse relationship betroeen TDS and discharge. During the speed-up event (22-24 June),TDS and discharge are uncorrelated. After the flood on $24 \mathrm{~J}$ une, in the post-event period, solute concentrations are independent of discharge.

band (Fig. 12), showing that TDS is independent of discharge during this period. During both the flood event and the post-event period, concentrations are higher than would have been predicted by the concentration-discharge relationship of the pre-cvent period.

The persistence of diurnal oscillations in chemistry during 22-24 Junc, while the amplitude of variations in the discharge is diminished, implies that during this period distinct pathways cxist transmitting low-solute water and highsolute water to the outlet strcam, and that the relative contributions from these pathways varicd diurnally (Fig. 8). The avcrage discharge during this 2 day event was higher than during the preceding 10 days. Normally, increases in discharge are accompanied by a decrease in TDS. During 2224 June, however, TDS was in the same range as in the preceding days (Fig. 12), implying either at greater flux or higher TDS from the high-solutc source during this period. After the 24 June flood, the combination of high solute concentrations and loss of diurnal fluctuations suggests that the discharge in the post-event period is dominated by water that had been stored subglacially, and that the diurnal flushes of dilute meltwater are completely overwhelmed by water from this source.

Several features of the water chemistry, detailed in Figure 13 , are of interest. Although the TDS after 24 June is similar to that during the low-flow period of the days preceding the flood, the spcciation is different. In particular, sodium is much more concentrated, $\mathrm{pH}$ is higher and $\mathrm{PCO}_{2}$ with which the water is in equilibrium is lower in the runoff after 24 June. The trend is less clear, but also suggestive of higher concentrations in the post-flood days, for potassium, silica and nitratc. None of these trends are correlated with the suspended-sediment pulse, which peaked before the solutc concentrations in bulk runoff shifted (Fig. 8), and therefore "post-mixing" reactions (Brown and others, 1994; Sharp and others, 1995) between dilute waters from surficial melt and sediment-laden waters at the bed are not a likely cause of the change in concentrations.

One of the most important weathering reactions responsible for the chemistry of runoff from glaciers, regard- 

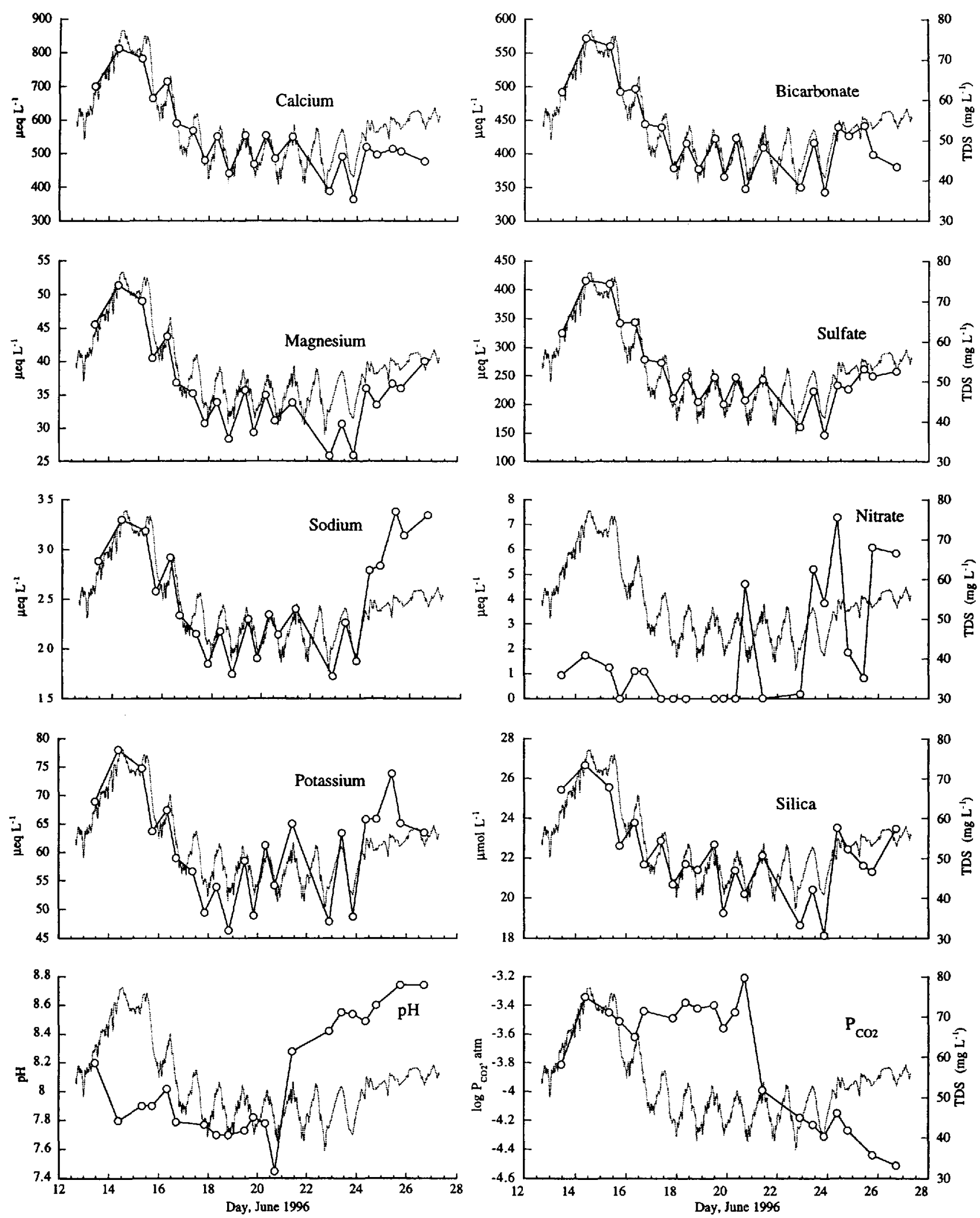

Fig. 13. Composition of Bench River water through time. Gray curves show TDS concentrations calculaled from EG measuremenls ( scale on right side), while connected points show measured composition of water samples (scales on left sides of plots).

less of the bedrock, is dissolution of trace quantities of carbonate minerals (Raiswell, 1984; Mast and others, 1990; Tranter and others, 1993; Brown and others, 1996b; Anderson and others, 1997; Blum and others, 1998), which increases the $\mathrm{pH}$ and releases calcium, magnesium and bicarbonate to the water. This reaction can be coupled to iron sulfide (c.g. pyrite) oxidation (Tranter and others, 1989, 1993), which produces sulfate and hydrogen ions capable of driving further carbonate dissolution. The effects of these pro- cesses can be seen in the Bench Glacier runoff in the high calcium, magnesium, bicarbonate and sulfate conccntrations. If anything, these species appear to be present in slightly lower concentrations following the 24 Junc flood, suggesting that the products of these reactions are being diluted. High $\mathrm{pH}$ and low $\mathrm{P}_{\mathrm{CO}_{2}}$ seen after 24 June are the characteristics one expects to see in waters that have cvolved in a system closed to atmospheric $\mathrm{CO}_{2}$ (Raiswell, 1984).

The enhanced sodium, potassium and silica concentra- 
tions after 24.June in the Bench River (Fig. 13) are consistent with a source from weathering of aluminosilicate minerals. These reactions are most likely to take place where water and sediments are in contact for long periods of time, as the kinetics of silicate-weathering reactions are slow (Lasaga and others, 1994). Tranter and others (1997) associated high silica, base-cation, bicarbonate and sulfate concentrations with the subglacial distributed flow system, because that is the only subglacial environment where there is sufficient contact time between sediments and water for acquisition of solutes in concentrations high enough to produce an observable shift in the runoff. We similarly infer that the high solute concentrations, and in particular the high cations and silica, and low $P_{\mathrm{CO}_{2}}$ of the post-flood period are indicative of the runoff being overwhelmed by water draining the distributed drainage system.

Finally, it is worth noting the nitrate in the runoff. Although the trend is not unequivocal, there is a tendency for nitrate to be present in measurable quantities (up to $7 \mu \mathrm{eq} \mathrm{L}^{-1}$ ) following the 24 June flood, while it is either undetected or present in very low concentrations before this flood (Fig. 13). Tranter and others (1997) noted mean nitrate concentrations of $27 \mu \mathrm{eq} \mathrm{L}{ }^{-1}$ in boreholes that appeared not to be connected to subglacial conduits, i.e. in waters from the distributed flow system at Haut Glacier d'Arolla, Switzerland. They suggested that the nitrate came from preferential clution of nitrate from the snowpack during early snowmelt, and that its presence demonstrates storage of water subglacially for periods on the order of months. The high nitrate in the runoff at Bench Glacier during a time when we infer that storcd meltwaters dominate the discharge is in keeping with this interpretation.

\section{Summary}

Drawing on evidence from the pattern of discharge, glacier surface velocities, sediment and solute concentrations, and physical obscrvations, wc can now build the following conceptual model of the spring event we observed at Bench Glacicr. The sunny wcather of 15-22 June produced meltwater at a rate greater than the subglacial drainage system could transmit. Consequently, water storage within the glacier increased. This storage may have been in any part of the glacier: within the snowpack, within englacial conduits or at the glacier bed. We believe that subglacial storage was the most important. Although either englacial or subglacial storage could produce the high water pressures we infer from the enhanced sliding velocities on 22-24 June, only release of subglacially stored water can explain the shift to high TDS and altercd speciation in the runoff after the speed-up event. During the period of sustained high sliding speeds, the glacier seemed to be in a quasi-cquilibrium with respect to water balance. The calculated meltwater production was approximately equal to the discharge over this interval, although peak meltwater production cach day exceeded the discharge at any time. Physical evidence in the form of high sediment concentration and large ice chunks appearing in the outlet stream suggests that new subglacial flow paths, which would provide routes for highsolute subglacial water to drain, were formed forcefully during this interval. Diurnal solute concentration variations remained intact, showing that some conduits capable of rapid transmission of recent meltwater through the glacier persisted through this period; however, increased solute flux during this time shows that a rescrvoir of highsolute water was being tapped. The culminating flood on 24 June released a huge pulse of suspended sediment and water, and put an end to the period of high sliding velocity. We infer that high subglacial pressures were relieved by this flood. However, in many ways the system docs not return to pre-event character. The mean sliding speed was lower, reflecting an increase in the mean effective stress at the bed. The chemistry of the runoff was altered by this event to a composition similar to distributed-system subglacial waters sampled clsewhere (c.g. Tranter and others, 1996), normally a dominant component of the runoff only during periods of low flow. For the remaining 3 days of observation, the discharge appears to be dominantly draining water that had been stored subglacially. Presumably, had we continued our measurements longer we would have seen the re-establishment of diurnal oscillations in the solute concentrations and discharge as the hydrologic system regained a balance.

\section{CONGLUSIONS}

Bench Glacier displayed a transient response in sliding, and in the chemistry and physical sediment delivered through the subglacial system, reflective of the reorganization of the hydrologic system at the bed. This event appeared to be caused by a period of inputs of meltwater in excess of the capacity of the subglacial drainage system. Repercussions in the discharge record, suspended-sediment concentrations and solute concentrations lasted for several days after the peak flood event, which we believe reflects the drawdown of subglacial water storage. Becausc Bench Glacier docs not have a complicated drainage area, and appears not to have a complex bed geometry, this event must be driven by internal responses that are common to all glaciers, and not unique to particular settings. The causes of such episodes may be more readily understood in small, simple glaciers such as Bench Glacier.

\section{ACKNOWLEDGEMENTS}

We wish to thank K. Goscinski for aid in the ficldwork, and $\mathrm{S}$. Boese at University of Wyoming and R. Franks in the Marine Analytical Laboratory at the University of California, Santa Cruz, for help with chemical analyses. We thank K. C. MacGregor and L. Perg for commenting on an earlier draft of the manuscript, and M. Tranter and an anonymous reviewer for their careful critiques. This study was funded in part through a U.S. National Science Foundation (NSF) Farth Sciences post-doctoral fellowship (EAR-9404465) to S.P.A., and through an NSF Presidential Young Investigator award to R.S.A. This is contribution No. 386 from the Institute of lectonics.

\section{REFERENCES}

Anderson, S. P. J. I. Irever and N. F. Humphrey, 1997. Chemical weathering in glacial environments. Geolog); 25 (5),399-402.

Barclay, D. J. and P. E. Calkin. 1996. 1000-ycar glacial and trec-ring chronologies from Prince William Sound, Alaska. Geol. Soc. Am. Abstr. Programs, $28(7), \mathrm{A}-362$.

Blum, J. D., C. A. Gazis, A. D. Jacobson and C. P. Chamberlain. 1998. Carbonate versus silicate weathering in the Raikhot watershed within the High Himalayan Crystalline Series. Geolog), 26(5), 411-414.

Braithwaite, R.J. 1995. Positive degree-day factors for ablation on the Greenland ice sheet studied by energy-balance modelling. 7. Glaciol, 
$41137,153-160$

Braithwaite, R.J. and O.B. Olesen. 1989. Calculation of glacier ablation from air tempcrature, West Greenland. In Oerlemans, J., ed. Glacier fut twations and climatic change. Dordrecht, etc., Kluwer Academic Publishers, 219-233.

Brown, G. H., M. J. Sharp, M. Tranter, A. M. Gurnell and P.W. Nicnow 1994. Impact of post-mixing chemical reactions on the major ion chemistry of bulk meltwaters draining the Haut Glacier d'Arolla. Valais, Switzerland. Hydrol. Processes, 8 5 i, 465-480.

Brown, G. H., M. Tranter and M.J. Sharp. 1996a. Experimental investigations of the wcathering of suspended scdiment by Alpine glacial meltwaters. Hydrol. Processes, 10 4), 579598

Brown, G. H., M. Sharp and M. Tranter, 1996b. Subglacial chemical erosion: scasonal variations in solutc provenance, Haut Glacier d'A rolla, Valais, Switzerland. Ann. Glaciol, 22, 2531.

Calkin, P. E. 1988. Holocene glaciation of Alaska and adjoining Yukon Territory, Canada Ouat. Si. Rez, 7(2), 159-184.

Church, M. and R. Gilbert. 1975. Proglacial fluvial and lacustrine environments. In Jopling, A.V and B. C. McDonald, eds. Glaciofuital and glaciolacustrine sedimentation. Tulsa, OK, Society of Economic Palcontologists and Mineralogists, 22-100. (SE.PM Special Publication 23.

Collins, D). N. 1979. Quantitative determination of the subghacial hydrulogy of two Alpine glaciers. .7. Glaciol, 23 89 ), 347-362.

Collins, D. N. 1995. Dissolution kinetics, transit times through subglacial hydrologiral pathways and diurnal variations of solute content of meltwaters draining from an Alpine glacier. Hydrol. Processes, 9, 897 -910.

Dietrich, W. E. 1982. Settling velocity of natural particles. Water Resour. Res. $18(6,1615-1626$

Drever, J. I. 1997. The geochemistry of natural waters: surface and groundwater en vizonments. Third edition. Englewood Cliffs, NJ, Prentice-Hall.

Fountain, A. G. and J. S. Walder, 1998. Water flow through temperate glaciers. Rez. Geophys, 36(3), 299 . 328

Gomez, B. 1987. Bedload. In Gurnell, A. M. and M. J. Clark, eds. Glacio-fluvial sediment transfer: an alpine perspective. Chichester, etc., John Wiley and Sons, 355-376.

Gurnell, A. M., G. H. Brown and M. 'Tranter. 1994. A sampling strategy to describe the temporal hydrochemical characteristics of an Alpine proglacial stream. IIydrol. Processes, 8(1), 1-25.

Hammer, K. M. and N. D. Smith. 1983. Sediment production and transpor in a proglacial stream: Hilda Glacier, Alberta, Canada. Boreas, 12(2). 91-106.

Harper, J.T., N. F. Humphrcy, W.'l. Pfeffer and B. C. Welch. 1996. Short wavelength variations in the horizontal velocity field of a valley glacier. CRREL Spec. Rep. 96-27, 41-48.

Harper, J.T., N. F. Humphrey and W.T. Pfeffer. 1998a. Crevasse pattern and the strain-rate tensor: a high-resolution comparison. f. Glaciol. $44146,68-76$.

Harper. J.T., N. F. Humphrey and W. T. Pfeffer. 1998b. Three-dimensional deformation measured in an Alaskan glacier. Science, 281 15381 , 1340-1342.

Hem, J. D. 1982. Conductance: a collective measure of dissolved ions. In Minear, R. A. and L. H. Keith, eds. Water analysis. Vol. I. New York, Academic Press Inc., 137-161.

Hooke, R. L.eB., P. Calla, P. Holmlund, M. Nilsson and A. Stroeven. 1989. A 3 year record of seasonal variations in surface velocity, Storglaciären, Sweden. 7. Glaciol, 35 (120), 235-247.

Hubbard, B. and P. Nienow. 1998. Alpine subglacial hydrology. Quat. Sci Rev., 16,939-955.

Humphrey, N. F. 1987. Coupling between water pressure and basal sliding in a linked-cavity hydraulic system. International Association of Hydrological Sciences Publication 170 Symposium at Vancouver 1987 - The Physical Basis of lre Sheet Modelling, 105-119.

Humphrey, N. F. and C. F. Raymond. 1994. Hydrology, erosion and sediment production in a surging glacicr: Varicgated Glacier, Alaska, 1982-83. 7. Glaciol., 40 136, 539552

Humphrey, N., C. Raymond and W. Harrison. 1986. Discharges of turbid water during mini-surges of Variegated Glacier, Alaska, U.S.A. 7. Glaiol., 32(111, 195-207.

Iken, A and R. A. Bindschadler. 1986. Combined measurements of subglacial water pressure and surface velocity of Findelengletscher. Switzerland: conclusions about drainage system and sliding mechanism. $\mathcal{J}$ Glaciol., 32110;, 10]-119.

Iken, A. and M. Truffer. 1997. The relationship between subglacial water pressure and velocity of Findelengletscher, Switzerland, during its ad- vance and retreat. 7. Glaciol, 43(144),328-338.

Iken, A., H. Röthlisberger, A. Flotron and W. Hacberli. 1983. The uplift of Unteraargletscher at the beginning of the melt season - a consequence of water storage at the bed? 7 . Glaciol, $29101,28-17$.

Jansson, P. 1996. Dynamics and hydrology of a small polythermal valley glacicr. Geogr. Ann., 78A (2-3), 171-180.

Kamb, B., H. Fingelhardt, M. A. Fahnestock, N. Humphrey, M. Meier and D. Stone. 1994. Mechanical and hydrologic basis for the rapid motion of a large tidewater glacier. 2. Interpretition. 7. Geophys. Res., 99:B8; $15,23 \mathrm{l}-15,244$

Kilpatrick, F. A. and E. D. Cobb. 1984. Mcasurement of discharge using tracers. In Techniques of water resources investigation. Book 3. Washington, DC: U.S. Geological Survey, chapter Alb.

Kite, G. 1994. Measuring glacier outflows using a computerized conductivity system. 7. Glaciol., $\mathbf{4 0} 134,9396$.

Lasaga, A. C., J. M. Soler, J. Ganor, T. E. Burch and K. L. Nagy. 1994 Chemical weathering rate laws and global geochemical cycles. Georhm. Cosmochim. Acta, 5810, 236!-2386.

Mast, M. A., J. I. Drever and J. Barnn. 1990. Chcmical weathering in the Loch Vale watershed, Rocky Mountain National Park, Colorado. Water Resour. Res, 26 12, 2971-2978.

Meier, M. and 9 others. 1994. Mechanical and hydrologic basis for the rapid motion of a large tidewater glacier. 1. Observations. 7. Geophys. Res., 99(B8), 15,219-15,229

Ostrem, G. 1975. Sediment transport in glacial meltwater streams. In Jopling, A.V. and B. C. McDonald, eds. Glaciofluvial and glaciolacustrine sedimentation. Tulsa, OK, Socicty of Economic Palcontologists and Mineralogists, 101 122. (SEPM Special Publication 23.)

Plafker, G., W.J. Nokleberg and J.S. Lull. 1989. Bedrock geology and tectonic evolution of the Wrangellia, Peninsular, and Chugach terranes along the Trans-Alaska Crustal Transcet in the Chugach Mountains and southern Copper River basin. F. Geophys. Res, 94(B4), 42554295.

Raiswell, R. 1984. Chemical models of solute acquisition in glacial mel watcrs. f. Glaciol., 30(104), 49-57.

Raymond, C. F., R. J. Benedic, W. D. Harrison. K. A. Echelmeyer and M Sturm. 1995. Hydrological discharges and motion of Fets and Black Rapids Glaciers, Alaska, U.S.A.: implications for the structure of their drainage systems. 7. Glaciol., 41 (138), 290-304.

Rouse, H. 1937. Modern conceptions of mechanics of fluid turbulence. Trans. Am. Soc. Civ. Eng., 102, 436-505.

Sharp, M., G. H. Brown, M. Tranter, I. G. Willis and B. Hubbard. 1995 Comments on the use of chemically based mixing models in glacier hydrology. 7. Glariol., 41 (138), 241-246.

Stone, D. B., G. K. C. Clarke and E.W. Blake. 1993. Subglacial measurement of turbidity and electrical conductivity. F. Glaciol, $39(132), 415-420$.

Tranter, M. and R. Raiswell. 1991. The composition of the englacial and subglacial component in bulk meltwaters draining the Gorncrgletscher, Swilzerland. F. Glaciol., 37 125,5966 .

Tranter, M., R. A. Mills and R. Raiswell. 1989. Chemical weathering reactions in Alpine glacial meltwaters. In Miles, D. L., ed. Proceedings of the olh International Symposium on Water-Rock Interaction, Malvern, 1989. Rotterdam, Balkema, 687690

Tranter, M., G. Brown, R. Raiswell, M. Sharp and A. Gurnell. 1993. A conceptual model of solute acquisition by Alpine glacial meltwaters. $\mathcal{F}$ Glaciol., 39 (133), 573-581.

Tranter, M., G. H. Brown, A. J. Hodson and A. M. Gurnell. 1996. Hydrochemistry as an indicator of subglacial drainage system structure: a comparison of Alpinc and sub-polar cnvironments. Hydrol. Processes, $10(4,541556$

Tranter, M. and 9 others. 1997. Variability in the chemical composition of in situ subglacial meltwaters. Hydrol. Processes, 11 (1), 59-78

Warburton, J. 1992. Observations of bed load transport and channel bed changes in a proglacial mountain stream. Arct. Alp. Res, 24/3, $195 \cdot 203$.

Welch, B. C., W.T. Pfeffer, J. T. Harper and N. F. Humphrev. 1998. Mapping subglacial surfaces of temperate valley glaciers by two-pass migration of a radio-echo sounding survey. 7. Glaciol, $44(146), 164-170$

Willis, I. C., K. S. Richards and M.J. Sharp. 1996. Links between proglacial stream suspended sediment dynamics, glacier hydrology and glacicr motion at Midtdalsbrcen, Norway. Hydrol. Processer, 10, 629-648.

Winkler, G. R., M. L. Silberman, A. Grantz, R. J. Miller and E. M. MacKevett, Jr. 1981. Geologic map and summary geochronology of the Valdez quadrangle, southern Alaska. U.S. Geol. Surv. Open File Rep. 80-892A 